\title{
Analisa Penjadwalan Proyek Menggunakan PDM dan Pert Serta Crash Project \\ (Studi kasus: Pembangunan Gedung Main Power House PT. Adhi Karya)
}

\author{
Suherman ${ }^{1}$, Amarina IIma ${ }^{2}$ \\ ${ }^{1,2}$ Jurusan Teknik Industri, Fakultas Sains dan Teknologi, UIN Sultan Syarif kasim Riau \\ E-mail: suher_aje@yahoo.co.id
}

\begin{abstract}
Abstrak
Pengendalian proyek diperlukan untuk memastikan bahwa pekerjaan yang akan dilaksanakan sesuai dengan waktu, biaya dan mutu yang terdapat didalam dokumen kontrak. Metode yang digunakan yaitu metode Precedence Diagram Method (PDM), Program Evaluation Review Technique (PERT) dan Crash Project. Penelitian dilakukan pada pekerjaan pembangunan gedung main power house (MPH) yang dilaksanakan oleh PT. Adhi Karya. Dari hasil penelitian didapat jalur kritis pada proyek adalah kegiatan AC-E-F-G-H-I-J-K-L dengan probabilitas penyelesaian proyek selama 110 hari (dengan pendekatan PDM) adalah 52\%. Sedangkan biaya optimal proyek adalah sebesar Rp 1.168.150.740,68 dengan percepatan durasi kegiatan finishing sebanyak 5 hari.
\end{abstract}

Kata Kunci: Penjadwalan proyek, PDM, PERT, Crash Project.

\section{Pendahuluan}

Perkembangan teknologi meningkatkan pembangunan pada setiap daerah, baik itu perkotaan maupun pedesaan. Pembangunan ditujukan untuk meningkatkan kesejahteraan masyarakat, misalnya pembangunan jalan, gedung, jembatan dan lainnya.

Dalam suatu proyek pembangunan, perencanaan merupakan masalah yang sangat penting. Suatu perencanaan diperlukan dan dipergunakan sebagai pedoman dalam melaksanakan proyek sehingga proyek dapat dilaksanakan dengan waktu yang efisien (Arianto, 2010).

Salah satu kontraktor yang bergerak di bidang konstruksi jasa adalah PT Adhi Karya.PT Adhi Karya sedang menjalankan proyek yang berada di Bandara Sultan Syarif Kasim II Pekanbaru Provinsi Riau. Proyek tersebut meliputi pekerjaan parkir, jalan dan lanjutan pembangunan gedung operasional dan perkantoran Bandara Sultan Syarif Kasim II dengan waktu pelaksanaan 240 hari kalender dan waktu pemeliharaan 180 hari kalender. Salah satunya adalah pembangunan gedung Main Power House (MPH).
Saat ini perencanaan dan penjadwalan proyektersebut hanya menggunakan metode barchart dan kurva-s.sehingga, tidak dapat terlihat kegiatan yang kritis atau tidak dapat ditunda pekerjaannya. Sehingga,jika ada salah satu kegiatan yang ditunda akan berdampak waktu penyelesaian proyek.Untuk itu, perlu dilakukan penelitian dengan metode PDM (Precedence Diagram Method) dan PERT (Project Evaluation and Review Technique) serta Crash Project.

\section{Tujuan Penelitian}

Adapun tujuan pada penelitian ini adalah:

1. Untuk mengetahui jalur kritis pada proyek.

2. Untuk mengetahui probabilitas penyelesaian proyek.

3. Untuk mengetahui biaya optimal proyek.

\section{Tinjauan Pustaka}

\section{Definisi Proyek}

Proyek adalah suatu urutan dan peristiwa yang dirancang dengan baik dengan suatu permulaan dan akhir yang diarahkan untuk mencapai suatu tujuan yang jelas (Gumilang, 2014). 


\section{Manajemen Proyek}

Manajemen proyek dapat diartikan sebagai penerapan fungsi-fungsi manajemen dalam suatu kegiatan proyek dengan kata lain merupakan suatu kegiatan yang mengatur jalannya kegiatan-kegiatan dalam pelaksanaan proyek untuk semua tahapan-tahapan proyek (Iman Soeharto,1995 dalam Raharja, 2014).

\section{Metode Network Diagram}

Ada beberapa macam metode analisis jaringan kerja yang dapat digunakan dalam penjadwalan waktu proyek, antara lain (Soeharto, 1999 dalam Arianto, 2010):

1. Critical Path Method (CPM)

2. Precedence Diagramming Method (PDM)

3. Project Evaluation and Review Technique (PERT)

\section{PDM (Precedence Diagram Method)}

Menurut Ervianto (2005) kelebihan

Precedence Diagram Method (PDM) dibandingkan dengan CPM adalah PDM tidak memerlukan kegiatan fiktif/dummy sehingga pembuatan jaringan menjadi lebih sederhana. Hal ini dikarenakan hubungan overlapping yang berbeda dapat dibuat tanpa menambah jumlah kegiatan (Arianto, 2010).

Pada PDM juga dikenal adanya konstrain. Satu konstrain hanya dapat menghubungkan dua node, karena setiap node memiliki dua ujung yaitu ujung awal atau mulai $=(\mathrm{S})$ dan ujung akhir atau selesai $=(\mathrm{F})$. Maka di sini terdapat empat macam konstrain (Soeharto,1999dalam Arianto, 2010), yaitu:

1. Konstrain selesai ke mulai - Finish to Start (FS)

Konstrain ini memberikan penjelasan hubungan antara mulainya suatu kegiatan dengan selesainya kegiatan terdahulu. Dirumuskan sebagai FS $(i-j)=a$ yang berartikegiatan (j) mulai a hari, setelah kegiatan yang mendahuluinya (i) selesai.

2. Konstrain mulai ke mulai - Start to Start (SS)

Memberikan penjelasan hubungan antara mulainya suatu kegiatan dengan mulainya kegiatan terdahulu. Atau SS $(i-j)=b$ yang berarti suatu kegiatan (j) mulai setelah b hari kegiatan terdahulu (i) mulai. Konstrain semacam ini terjadi bila sebelum kegiatan terdahulu selesai $100 \%$ maka kegiatan (j) boleh mulai setelah bagian tertentu dari kegiatan (i) selesai.

3. Konstrain selesai ke selesai - Finish to Finish (FF).

Memberikan penjelasan hubungan antara selesainya suatu kegiatan dengan selesainya kegiatan terdahulu. Atau FF (i-j) = c yang berarti suatu kegiatan (j) selesai setelah c hari kegiatan terdahulu (i) selesai. Konstrain semacam ini mencegah selesainyasuatu kegiatan mencapai 100\% sebelum kegiatan yang terdahulu telah sekian $(=\mathrm{c})$ hari selesai.

4. Konstrain mulai ke selesai - Start to Finish (SF)

Menjelaskan hubungan antara selesainya kegiatan dengan mulainya kegiatan terdahulu. Dituliskan dengan SF $(\mathrm{i}-\mathrm{j})=\mathrm{d}$, yang berarti suatu kegiatan (j) selesai setelah $\mathrm{d}$ hari kegiatan (i) terdahulu mulai.

\begin{tabular}{|c|c|c|c|c|c|c|c|c|}
\hline & & & & \multicolumn{5}{|c|}{ FF ij } \\
\hline \multirow{2}{*}{$\begin{array}{l}\text { ES } \\
\text { LS }\end{array}$} & \multirow{2}{*}{\multicolumn{2}{|c|}{$\begin{array}{c}\text { JENIS } \\
\text { KEGIATAN }\end{array}$}} & $\mathrm{EF}$ & \multirow{4}{*}{ FS ij } & ES & \multirow{2}{*}{\multicolumn{2}{|c|}{$\begin{array}{c}\text { JENIS } \\
\text { KEGIATAN }\end{array}$}} & $\mathrm{EF}$ \\
\hline & & & \multirow{2}{*}{ LF } & & LS & & & LF \\
\hline \multicolumn{2}{|c|}{ NO. KEG } & DURASI & & & \multicolumn{2}{|c|}{ NO. KEG } & \multicolumn{2}{|c|}{ DURASI } \\
\hline \multicolumn{4}{|c|}{ SS ij } & & & & & \\
\hline & & & & SF ij & & & & \\
\hline
\end{tabular}

Gambar 1.Hubungan Kegiatan i dan j (Sumber: Arianto, 2010)

\section{Teknik Perhitungan PDM}

Metode PDM adalah jaringan kerja yang termasuk klasifikasi Activity On Node (AON). Disini kegiatan dituliskan dalam node yang umumnya berbentuk segi empat, sedangkan anak panah hanya sebagai penunjuk hubungan antara kegiatan-kegiatan yang bersangkutan (Soeharto. 1999 dalam Arianto, 2010).

\begin{tabular}{|c|c|c|c|}
\hline ES & \multirow{2}{*}{\multicolumn{2}{|c|}{$\begin{array}{c}\text { JENIS } \\
\text { KEGIATAN }\end{array}$}} & $\mathrm{EF}$ \\
\hline LS & & & LF \\
\hline \multicolumn{2}{|c|}{ NO. KEG } & \multicolumn{2}{|c|}{ DURASI } \\
\hline
\end{tabular}

Gambar 2.Lambang Kegiatan PDM (Sumber: Arianto, 2010) 
Keterangan:

$\begin{array}{ll}\text { ES } & : \text { Earliest Start } \\ \text { LS } & : \text { Latest Start } \\ \text { EF } & : \text { Earliest Finish } \\ \text { LF } & : \text { Latest Finish }\end{array}$

Berikut adalah rumus untuk perhitungan PDM adalah (Amani, 2012):

1. Perhitungan maju

a. Hubungan kegiatan finish to finish

$\mathrm{EF}_{\mathrm{j}}=\mathrm{EF}_{\mathrm{i}}+\mathrm{FF}_{\mathrm{i}} \ldots .$.

$\mathrm{ES}_{\mathrm{j}}=\mathrm{EF}_{\mathrm{j}}-\mathrm{D}_{\mathrm{j}}$

b. Hubungan kegiatan finish to start

$\mathrm{ES}_{\mathrm{j}}=\mathrm{EF}_{\mathrm{i}}+\mathrm{FS}_{\mathrm{ij} . .}$

$\mathrm{EF}_{\mathrm{j}}=\mathrm{ES}_{\mathrm{j}}+\mathrm{D}_{\mathrm{j}}$

c. Hubungan kegiatan start to start

$\mathrm{ES}_{\mathrm{j}}=\mathrm{ES}_{\mathrm{i}}+\mathrm{SS}_{\mathrm{ij}} \ldots \ldots$

$\mathrm{EF}_{\mathrm{j}}=\mathrm{ES}_{\mathrm{j}}+\mathrm{D}_{\mathrm{j}}$

d. Hubungan kegiatan start to finish

$\mathrm{EF}_{\mathrm{j}}=\mathrm{ES}_{\mathrm{i}}+\mathrm{SF}_{\mathrm{ij}} \ldots .$.

$\mathrm{ES}_{\mathrm{j}}=\mathrm{EF}_{\mathrm{j}}-\mathrm{D}_{\mathrm{j}}$

2. Perhitungan mundur

a. Hubungan kegiatan finish to finish

$\mathrm{LF}_{\mathrm{i}}=\mathrm{LF}_{\mathrm{j}}-\mathrm{FF}_{\mathrm{ij}}$

$\mathrm{LS}_{\mathrm{i}}=\mathrm{LF}_{\mathrm{i}}-\mathrm{D}_{\mathrm{i}}$

b. Hubungan kegiatan finish tostart

$\mathrm{LF}_{\mathrm{i}}=\mathrm{LS}_{\mathrm{j}}-\mathrm{FS}_{\mathrm{ij}}$

$\mathrm{LS}_{\mathrm{i}}=\mathrm{LF}_{\mathrm{i}}-\mathrm{D}_{\mathrm{i}}$

c. Hubungan kegiatan start to start

$\mathrm{LS}_{\mathrm{i}}=\mathrm{LS}_{\mathrm{j}}-\mathrm{SS}_{\mathrm{ij}}$

$\mathrm{LF}_{\mathrm{i}}=\mathrm{LS}_{\mathrm{i}}+\mathrm{D}_{\mathrm{i}}$

d. Hubungan kegiatan start to finish

$\mathrm{LS}_{\mathrm{i}}=\mathrm{LF}_{\mathrm{j}}-\mathrm{SF}_{\mathrm{ij}}$

$\mathrm{LF}_{\mathrm{i}}=\mathrm{LS}_{\mathrm{i}}+\mathrm{D}_{\mathrm{i}}$

3. Suatu kegiatan dikatakan kritis, apabila:

a. waktu mulai paling awal dan paling akhir sama $\mathrm{ES}=\mathrm{LS}$

b. waktu selesai paling awal dan akhir harus sama $\mathrm{EF}=\mathrm{LF}$

c. kurun waktu kegiatan adalah sama dengan perbedaan waktu selesai paling akhir dengan waktu mulai paling awal LF $-\mathrm{ES}=\mathrm{D}$

d. Total float $=0=\mathrm{LF}-\mathrm{EF}=\mathrm{LS}-\mathrm{ES}$

PERT (Project Evaluation and Review Technique)

Metode PERT merupakan suatu metode yang memasukkan unsur-unsur probabilistas, karena mempunyai kadar ketidakpastian pada kurun waktu aktivitas yang berhubungan dengan pelaksanaan proyek. Inti dari PERT pada dasarnya adalah menentukan besarnya peluang proyek dapat diselesaikan sesuai dengan waktu yang telah ditargetkan. PERT memakai pendekatan yang menganggap bahwa kurun waktu kegiatan tergantung pada banyak faktor dan variansi, sehingga lebih baik perkiraan diberi rentang (range), yaitu memakai 3 angka estimasi bagi setiap aktivitas yaitu optimistik (a), pesimistik (b) dan yang paling mungkin (m). Dengan memberikan tiga angka estimasi tersebut maka akan memberikan rentang yang lebih besar dalam melakukan estimasi kurun waktu kegiatan dibanding satu angka deterministik (Abisetyo, 2010).

\section{Teknik Perhitungan PERT}

PERT adalah teknik manajemen proyek yang menggunakan tiga perkiraan waktu untuk tiap kegiatan (Prasetya dan Lukiastuti, 2009:33). Tiga angka estimasi tersebut tersebut, yaitu, a, b, dan $\mathrm{m}$ yang mempunyai arti sebagai berikut (Soeharto, 1999 dalam Arianto, 2010):

1. $\mathrm{a}=$ kurun waktu optimistik (optimistic duration time), yaitu durasi tercepat yang dibutuhkan untuk menyelesaikan suatu kegiatan bila segala sesuatunya berjalan dengan baik.

2. $\mathrm{m}=$ kurun waktu yang paling mungkin (most likely time), yaitu durasi yang paling sering terjadi bila suatu kegiatan dilakukan berulang-ulang dengan kondisi yang hampir sama.

3. $\mathrm{b}=$ kurun waktu pesimistik (pessimistic duration time), yaitu durasi yang paling lama dibutuhkan untuk menyelesaikan suatu kegiatan bila segala sesuatunya berjalan dalam kondisi buruk.

Adapun untuk mendapatkan nilai mean durasi kegiatan yang diharapkan te (expected duration) dan standar deviasi kegiatan dari setiap kegiatan adalah sebagai berikut (Uher, 1996 dalam Arianto, 2010):

$$
\begin{aligned}
& \mathrm{te}=\frac{\mathrm{a}+4 \mathrm{~m}+\mathrm{b}}{6} \\
& \mathrm{~s}=\frac{\mathrm{b}-\mathrm{a}}{6}
\end{aligned}
$$

Dimana:

Te = mean durasi kegiatan yangdiharapkan

a = adalah waktu optimistik

$\mathrm{m} \quad=$ adalah waktu paling mungkin

$\mathrm{b}=$ adalah waktu pesimistik 
S $\quad=$ adalah standar deviasi kegiatan

Kemudian durasi proyek yang diharapkan

Te (Uher, 1996:153) adalah jumlah durasi dari kegiatan kritis dengan asumsi bahwa semua kegiatan adalah independen. Hal itu berarti nilai mean dari durasi proyek yang diharapkan terdistribusi normal sesuai dengan Central Limit Theorem (Bhattacharya dan Johnson, 1977) yang menyatakan bahwa dalam suatu populasi, fungsi distribusi apapun dapat diasumsikan sebagai fungsi distribusi normal jika jumlah sample cukup banyak. Adapun standar deviasi dari distribusi durasi proyek yang diharapkan $\mathrm{S}$ adalah akar jumlah kuadrat dari standar deviasi pada kegiatan kritis (Arianto, 2010).

$\mathrm{Te}=\sum$ (te) untuk kegiatan kritis

$\mathrm{S}=\sqrt{\sum s^{2}}$ untuk kegiatan kritis

$\mathrm{Z}=\frac{\mathrm{Ts}-\mathrm{Te}}{\mathrm{s}}$

Dimana:

$\mathrm{Te}=$ waktu penyelesaian proyek yang diharapkan

$\mathrm{Te}=$ mean durasi kegiatan yang diharapkan

$\mathrm{S}=$ standar deviasi dari distribusi durasi proyek yang diharapkan

$\mathrm{S}=$ standar deviasi kegiatan

$\mathrm{Ts}=$ target waktu penyelesaian proyek

$\mathrm{Z}=$ nilai probabilitas

\section{Perhitungan Biaya}

Mempercepat waktu penyelesaian proyek adalah suatu usaha menyelesaian proyek lebih awal dari waktu penyelesaian dalam keaadaan normal. Dengan diadakannya percepatan proyek ini akan terjadi pengurangan durasi kegiatan yang akan diadakan crash program. Durasi crashing maksimum suatu aktivitas adalah durasi tersingkat untuk menyelesaikan suatu aktivitas yang secara teknis masih mungkin dengan asumsi sumber daya bukan merupakan hambatan (Soeharto, 1997 dalam Frederika, 2010).

Biaya lembur per hari $=$

(jam kerja lemburpertama x 1,5 x upah satu jam normal)+ (jam kerja lembur berikutnya x 2 upahsatu jam normal)

\section{Metode Penelitian}

Pada metodologi penelitian atau tahaptahap penelitian ini akan diuraikan yang dilalui dari awal sampai akhir, yaitu studi literatur, penelitian pendahuluan, identifikasi masalah, penetapan tujuan, penentuan batasan, pengumpulan data, pengolahan data, analisa serta kesimpulan dan saran.

\section{Hasil dan Pembahasan}

\section{Pengumpulan Data}

Berikut rincian kegiatan pembangunan gedung Main Power House (MPH):

Tabel 1. Rincian Kegiatan Proyek Gedung Main Power House (MPH)

\begin{tabular}{|c|c|c|c|c|}
\hline No & Uraian & $\begin{array}{c}\text { Tgl. } \\
\text { Mulai }\end{array}$ & $\begin{array}{c}\text { Tgl. } \\
\text { Selesai }\end{array}$ & $\begin{array}{l}\text { Durasi } \\
\text { (Hari) }\end{array}$ \\
\hline & Gedung МРН & $\begin{array}{l}\text { 18- } \\
\text { Mar- } \\
15\end{array}$ & $\begin{array}{c}20- \\
\text { Jul-15 }\end{array}$ & $\begin{array}{c}125 \\
\text { Hari }\end{array}$ \\
\hline 1 & \multicolumn{4}{|l|}{ Struktur } \\
\hline & Pekerjaan Selasar & $\begin{array}{l}14- \\
\text { May- } \\
15\end{array}$ & $\begin{array}{c}03- \\
\text { Jun-15 }\end{array}$ & $\begin{array}{c}21 \\
\text { Hari }\end{array}$ \\
\hline & $\begin{array}{l}\text { Pekerjaan } \\
\text { Drainase Terbuka }\end{array}$ & $\begin{array}{l}\text { 04-Jun- } \\
15\end{array}$ & $\begin{array}{c}24- \\
\text { Jun-15 }\end{array}$ & $\begin{array}{c}21 \\
\text { Hari }\end{array}$ \\
\hline & Pekerjaan Tangga & $\begin{array}{c}18- \\
\text { Mar-15 }\end{array}$ & $\begin{array}{c}08- \\
\text { Apr-15 } \\
\end{array}$ & $\begin{array}{c}22 \\
\text { Hari } \\
\end{array}$ \\
\hline & $\begin{array}{l}\text { Pekerjaan } \\
\text { Mezzanine } \\
\text { Diruang Gudang } \\
\text { Oli }\end{array}$ & $\begin{array}{l}09- \\
\text { Apr-15 }\end{array}$ & $\begin{array}{c}4- \\
\text { May- } \\
15\end{array}$ & $\begin{array}{c}26 \\
\text { Hari }\end{array}$ \\
\hline 2 & \multicolumn{4}{|l|}{ Arsitektur } \\
\hline & $\begin{array}{l}\text { Pekerjaan } \\
\text { Pasangan Dinding }\end{array}$ & $\begin{array}{c}\text { 5-May- } \\
15 \\
\end{array}$ & $\begin{array}{c}01- \\
\text { Jun-15 }\end{array}$ & $\begin{array}{c}28 \\
\text { Hari } \\
\end{array}$ \\
\hline & $\begin{array}{l}\text { Pekerjaan Pelapis } \\
\text { Lantai \& Dinding }\end{array}$ & $\begin{array}{c}\text { 5-May- } \\
15\end{array}$ & $\begin{array}{c}22- \\
\text { Jun-15 }\end{array}$ & $\begin{array}{c}49 \\
\text { Hari }\end{array}$ \\
\hline & Pekerjaan Sanitair & $\begin{array}{c}\text { 23-Jun- } \\
15 \\
\end{array}$ & $\begin{array}{c}30- \\
\text { Jun-15 }\end{array}$ & 8 Hari \\
\hline & $\begin{array}{l}\text { Pekerjaan Dak } \\
\text { Atap }\end{array}$ & $\begin{array}{c}\text { 5-May- } \\
15\end{array}$ & $\begin{array}{c}04- \\
\text { Jun-15 }\end{array}$ & $\begin{array}{c}31 \\
\text { Hari } \\
\end{array}$ \\
\hline & $\begin{array}{l}\text { Pekerjaan Kusen, } \\
\text { Pintu, Jendela }\end{array}$ & $\begin{array}{l}19- \\
\text { May- } \\
15\end{array}$ & $\begin{array}{c}24- \\
\text { Jun-15 }\end{array}$ & $\begin{array}{c}37 \\
\text { Hari }\end{array}$ \\
\hline & $\begin{array}{l}\text { Pekerjaan } \\
\text { Finishing }\end{array}$ & $\begin{array}{c}19- \\
\text { May- } \\
15 \\
\end{array}$ & $\begin{array}{l}\text { 20-Jul- } \\
15\end{array}$ & $\begin{array}{c}63 \\
\text { Hari }\end{array}$ \\
\hline & $\begin{array}{l}\text { Pekerjaan Rumah } \\
\text { Pompa }\end{array}$ & $\begin{array}{c}\text { 5-May- } \\
15 \\
\end{array}$ & $\begin{array}{c}22- \\
\text { Jun-15 } \\
\end{array}$ & $\begin{array}{c}49 \\
\text { Hari } \\
\end{array}$ \\
\hline 3 & \multicolumn{4}{|c|}{ Mekanikal \& Elektrikal } \\
\hline & $\begin{array}{l}\text { Elektrikal Arus } \\
\text { Kuat }\end{array}$ & $\begin{array}{c}09- \\
\text { Apr-15 } \\
\end{array}$ & $\begin{array}{c}01- \\
\text { Jun-15 } \\
\end{array}$ & $\begin{array}{c}54 \\
\text { Hari } \\
\end{array}$ \\
\hline
\end{tabular}

(Sumber: Pengumpulan Data PT Adhi Karya, 2015)

Tabel 2. Rincian Biaya Langsung Gedung Main Power House (MPH)

\begin{tabular}{|c|l|c|}
\hline $\begin{array}{c}\text { N } \\
\text { o }\end{array}$ & \multicolumn{1}{|c|}{ Uraian Pekerjaan } & $\begin{array}{c}\text { Jumlah } \\
\text { Harga Rp. }\end{array}$ \\
\hline & $\begin{array}{l}\text { Gedung Main Power House } \\
\text { (MPH) }\end{array}$ & \\
\hline I & Struktur & $\mathbf{3 3 4 , 0 3 5 , 4 7}$ \\
\hline
\end{tabular}




\begin{tabular}{|c|c|c|}
\hline & & $\begin{array}{r}2.70 \\
\end{array}$ \\
\hline & 1. Pekerjaan Selasar & $\begin{array}{r}41,014,700 \\
.70\end{array}$ \\
\hline & 2. Pekerjaan Drainase Terbuka & $\begin{array}{r}191,366,63 \\
7.30 \\
\end{array}$ \\
\hline & 3. Pekerjaan Tangga & $\begin{array}{r}27,410,000 \\
.00\end{array}$ \\
\hline & $\begin{array}{l}\text { 4. Pekerjaan Mezzanine Di } \\
\text { Ruang Gudang Oli }\end{array}$ & $\begin{array}{r}74,244,134 \\
, 70 \\
\end{array}$ \\
\hline II & Arsitektur & $\begin{array}{r}723,350,01 \\
8.40\end{array}$ \\
\hline & $\begin{array}{l}\text { 1. Pekerjaan Pasangan } \\
\text { Dinding }\end{array}$ & $\begin{array}{r}66,859,605 \\
, 00 \\
\end{array}$ \\
\hline & $\begin{array}{l}\text { 2. Pekerjaan Pelapis Lantai \& } \\
\text { Dinding }\end{array}$ & $\begin{array}{r}177,188,77 \\
8.00 \\
\end{array}$ \\
\hline & 3. Pekerjaan Sanitair & $\begin{array}{r}8,635,440 . \\
00 \\
\end{array}$ \\
\hline & 4. Pekerjaan Dak Atap & $\begin{array}{r}119,396,16 \\
9.40 \\
\end{array}$ \\
\hline & $\begin{array}{l}\text { 5. Pekerjaan Kusen, Pintu Dan } \\
\text { Jendela }\end{array}$ & $\begin{array}{r}270,700,80 \\
0.00\end{array}$ \\
\hline & 6. Pekerjaan Finishing & $\begin{array}{r}70,903,850 \\
.00 \\
\end{array}$ \\
\hline & 7. Pekerjaan Rumah Pompa & $\begin{array}{r}9,665,376 . \\
00\end{array}$ \\
\hline $\begin{array}{c}\text { II } \\
\text { I }\end{array}$ & Mekanikal \& Elektrikal & $\begin{array}{r}84,608,420 \\
.00\end{array}$ \\
\hline & 1. Elektrikal Arus Kuat & $\begin{array}{r}84,608,420 \\
.00\end{array}$ \\
\hline & Jumlah & $\begin{array}{r}1,141,993 \\
911.10 \\
\end{array}$ \\
\hline
\end{tabular}

(Sumber: Pengumpulan Data PT Adhi Karya, 2015)

Tabel 3. Rincian Biaya Tidak Langsung Gedung Main Power House (MPH)

\begin{tabular}{|c|c|}
\hline Rincian & Biaya (Rp) \\
\hline Jumlah & $26,776.580,32$ \\
\hline
\end{tabular}

(Sumber: Pengumpulan Data PT Adhi Karya, 2015)

Tabel 4. Rincian Biaya Upah/ Jam

\begin{tabular}{|l|c|}
\hline \multicolumn{1}{|c|}{ Kegiatan } & Upah (Rp) / Jam \\
\hline Pekerjaan Tangga & 447.100 \\
\hline $\begin{array}{l}\text { Pekerjaan Mezzanine Diruang } \\
\text { Gudang Oli }\end{array}$ & 769.300 \\
\hline Elektrikal Arus Kuat & 297.000 \\
\hline Pekerjaan Pasangan Dinding & 205.900 \\
\hline Pekerjaan Dak Atap & 104.600 \\
\hline $\begin{array}{l}\text { Pekerjaan Pelapis Lantai \& } \\
\text { Dinding }\end{array}$ & 148.600 \\
\hline Pekerjaan Rumah Pompa & 220.000 \\
\hline Pekerjaan Selasar & 189.500 \\
\hline $\begin{array}{l}\text { Pekerjaan Kusen, Pintu, } \\
\text { Jendela }\end{array}$ & 880.000 \\
\hline Pekerjaan Finishing & 198.000 \\
\hline Pekerjaan Drainase Terbuka & 88.000 \\
\hline
\end{tabular}

\begin{tabular}{|l|c|}
\hline Pekerjaan Sanitair & \multicolumn{2}{|c|}{87.200} \\
\hline $\begin{array}{c}\text { Sumber: } \\
\text { 2015) }\end{array}$
\end{tabular}

\section{Pengolahan Data}

\section{Diagram Network PDM}

Berikut adalah Rekapitulasi rincian kegiatan gedung Main Power House (MPH) pada diagram network PDM.

Tabel 5. Rekapitulasi rincian kegiatan gedung Main Power House (MPH)

\begin{tabular}{|c|c|c|c|c|c|}
\hline $\begin{array}{l}\mathbf{N} \\
\mathbf{0}\end{array}$ & $\begin{array}{c}\text { URAIA } \\
\mathbf{N}\end{array}$ & $\begin{array}{l}\text { Kode } \\
\text { Kegiat } \\
\text { an }\end{array}$ & $\begin{array}{l}\text { Keterkai } \\
\text { tan } \\
\text { Kegiatan }\end{array}$ & $\begin{array}{l}\text { Dur } \\
\text { asi } \\
\text { (Har } \\
\text { i) }\end{array}$ & $\begin{array}{c}\text { Konstr } \\
\text { ain }\end{array}$ \\
\hline 1 & $\begin{array}{l}\text { Pekerja } \\
\text { an } \\
\text { Tangga }\end{array}$ & A & - & 22 & - \\
\hline 2 & $\begin{array}{l}\text { Pekerja } \\
\text { an } \\
\text { Mezzan } \\
\text { ine } \\
\text { Diruang } \\
\text { Gudang } \\
\text { Oli }\end{array}$ & B & A & 26 & $\begin{array}{l}\text { FS }(1- \\
2)=0\end{array}$ \\
\hline 3 & $\begin{array}{l}\text { Elektrik } \\
\text { al Arus } \\
\text { Kuat }\end{array}$ & $\mathrm{C}$ & A & 54 & $\begin{array}{l}\text { FS }(1- \\
3)=0\end{array}$ \\
\hline 4 & $\begin{array}{l}\text { Pekerja } \\
\text { an } \\
\text { Pasanga } \\
\mathrm{n} \\
\text { Dinding }\end{array}$ & D & B & 28 & $\begin{array}{l}\text { FS }(2- \\
4)=0\end{array}$ \\
\hline 5 & $\begin{array}{l}\text { Pekerja } \\
\text { an Dak } \\
\text { Atap }\end{array}$ & $\mathrm{E}$ & $\mathrm{C}$ & 31 & $\begin{array}{l}\text { SS }(3- \\
5)=27\end{array}$ \\
\hline 6 & $\begin{array}{l}\text { Pekerja } \\
\text { an } \\
\text { Pelapis } \\
\text { Lantai } \\
\& \\
\text { Dinding }\end{array}$ & $\mathrm{F}$ & $\mathrm{C}$ & 49 & $\begin{array}{l}\text { SS (3- } \\
6)=27\end{array}$ \\
\hline 7 & $\begin{array}{l}\text { Pekerja } \\
\text { an } \\
\text { Rumah } \\
\text { Pompa }\end{array}$ & G & $\mathrm{C}$ & 49 & $\begin{array}{l}\text { SS (3- } \\
7)=27\end{array}$ \\
\hline 8 & $\begin{array}{l}\text { Pekerja } \\
\text { an } \\
\text { Selasar }\end{array}$ & $\mathrm{H}$ & $\begin{array}{c}\mathrm{D}, \mathrm{E}, \mathrm{F}, \\
\mathrm{G}\end{array}$ & 21 & $\begin{array}{l}\text { SS }(4- \\
8)=10 \\
\text { SS }(5- \\
8)=10 \\
\text { SS }(6- \\
8)=10 \\
\text { SS }(7- \\
8)=10\end{array}$ \\
\hline 9 & $\begin{array}{l}\text { Pekerja } \\
\text { an } \\
\text { Kusen, } \\
\text { Pintu, } \\
\text { Jendela }\end{array}$ & I & $\mathrm{H}$ & 37 & $\begin{array}{l}\text { SS (8- } \\
9)=6\end{array}$ \\
\hline 1 & Pekerja & $\mathrm{J}$ & $\mathrm{H}$ & 63 & SS (8- \\
\hline
\end{tabular}




\begin{tabular}{|c|c|c|c|c|c|}
\hline 0 & $\begin{array}{l}\text { an } \\
\text { Finishin } \\
\mathrm{g}\end{array}$ & & & & 10) $=6$ \\
\hline $\begin{array}{l}1 \\
1\end{array}$ & $\begin{array}{l}\text { Pekerja } \\
\text { an } \\
\text { Drainas } \\
\text { e } \\
\text { Terbuka }\end{array}$ & K & I, J & 21 & $\begin{array}{l}\mathrm{SS}= \\
(9-11) \\
=17 \\
\mathrm{SS}= \\
(10-11) \\
=17\end{array}$ \\
\hline $\begin{array}{l}1 \\
2\end{array}$ & $\begin{array}{l}\text { Pekerja } \\
\text { an } \\
\text { Sanitair }\end{array}$ & $\mathrm{L}$ & $\mathrm{K}$ & 8 & $\begin{array}{l}\text { SS }(11- \\
12)=20\end{array}$ \\
\hline
\end{tabular}

(Sumber: Pengolahan Data, 2015)

Berdasarkan tabel di atas, berikut adalah diagram network-nya:

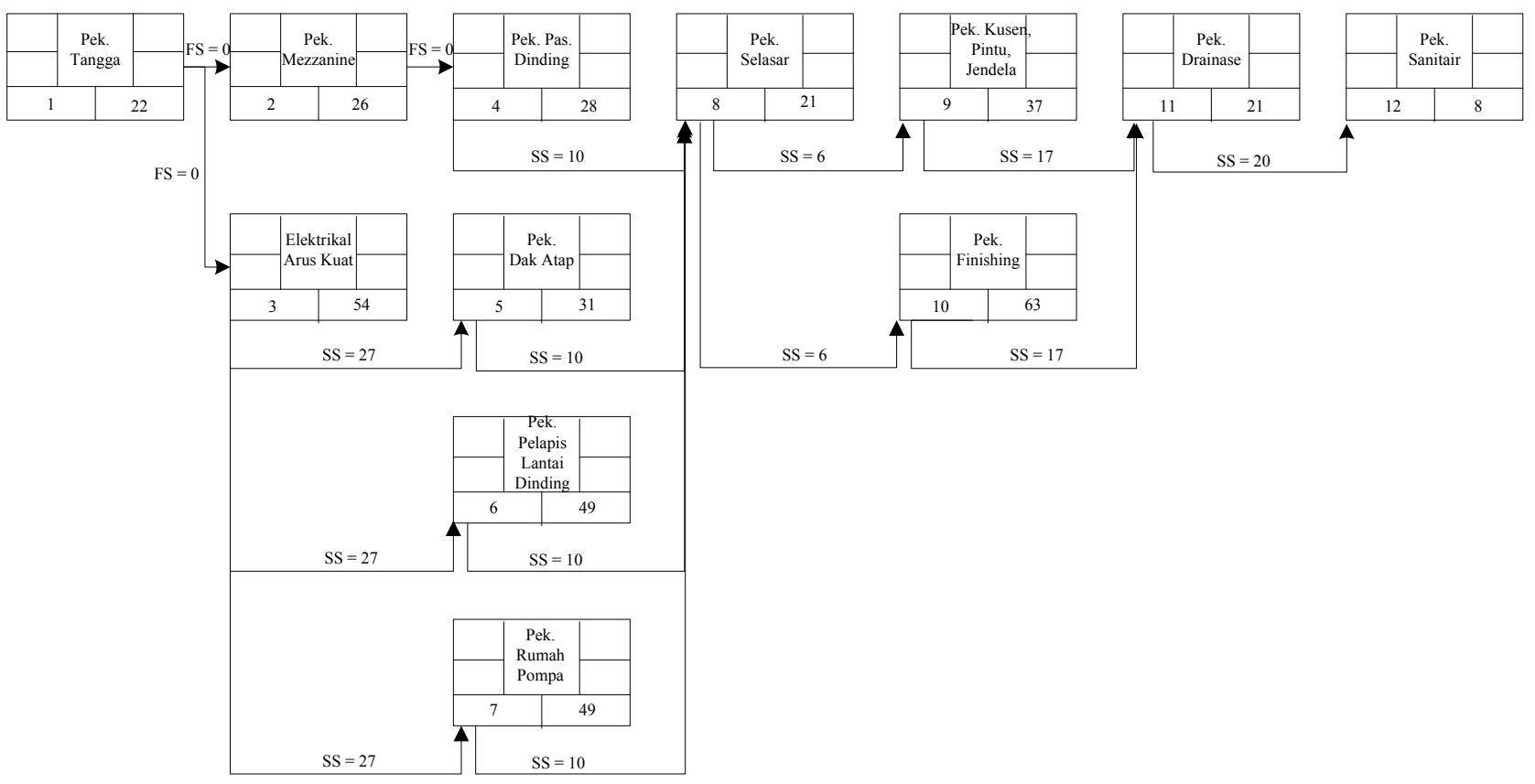

Gambar 3. Precedence Diagram Proyek Main Power House (MPH)

(Sumber: Pengolahan Data, 2015)

\section{Perhitungan Maju dan Perhitungan Mundur}

Perhitungan maju dan perhitungan mundur dibuat berdasarkan network diagram yang telah dibuat sebelumnya. Berikut adalah hasil dari perhitungan maju dan perhitungan mundur:

Tabel 6. Perhitungan Maju dan Perhitungan Mundur

\begin{tabular}{|l|ll|}
\hline \multicolumn{1}{|c|}{ Perhitungan Maju } & \multicolumn{2}{|c|}{ Perhitungan Mundur } \\
\hline Kegiatan A & Kegiatan L & \\
$\mathrm{ES}=0$ & $\mathrm{LF}=110$ & $=102$ \\
$\mathrm{EF}=0+22=22$ & $\mathrm{LS}=110-8$ & $=82$ \\
\hline Kegiatan B & Kegiatan $\mathrm{K}$ & \\
$\mathrm{ES}=22+0=22$ & $\mathrm{LS}=103-21$ & $=103$ \\
$\mathrm{EF}=22+26=48$ & LF $=82+21$ & \\
\hline Kegiatan C & Kegiatan J & \\
$\mathrm{ES}=22+0=22$ & LS $=128-63$ & $=65$ \\
$\mathrm{EF}=22+54=76$ & LF $=65+63$ & $=128$ \\
\hline Kegiatan D & Kegiatan I & \\
\hline
\end{tabular}

\begin{tabular}{|l|ll|}
\hline $\mathrm{ES}=22+0=22$ & $\mathrm{LS}=102-37$ & $=65$ \\
$\mathrm{EF}=22+28=50$ & $\mathrm{LF}=65+37$ & $=102$ \\
\hline Kegiatan $\mathrm{E}$ & Kegiatan $\mathrm{H}$ & \\
$\mathrm{ES}=22+27=49$ & $\mathrm{I}-\mathrm{H}$ & \\
$\mathrm{EF}=49+31=80$ & $\mathrm{LS}=80-21$ & $=59$ \\
& $\mathrm{LF}=59+21 \quad=80$ \\
& $\mathrm{~J}-\mathrm{H}$ & \\
& $\mathrm{LS}=80-21$ & $=59$ \\
& $\mathrm{LF}=59+21$ & $=80$ \\
\hline Kegiatan $\mathrm{F}$ & Kegiatan $\mathrm{G}$ & \\
$\mathrm{ES}=22+27=49$ & $\mathrm{LS}=98-49 \quad=49$ \\
$\mathrm{EF}=49+49=98$ & $\mathrm{LF}=49+49=98$ \\
\hline
\end{tabular}

\begin{tabular}{|l|ll|}
\hline \multicolumn{1}{|c|}{ Perhitungan Maju } & \multicolumn{2}{|c|}{ Perhitungan Mundur } \\
\hline Kegiatan $\mathrm{G}$ & Kegiatan $\mathrm{F}$ & \\
$\mathrm{ES}=22+27=49$ & $\mathrm{LS}=98-49 \quad=49$ \\
$\mathrm{EF}=49+49=98$ & $\mathrm{LF}=49+49 \quad=$ \\
\hline
\end{tabular}


Vol. 2, No. 1, 2016

Jurnal Hasil Penelitian dan Karya Ilmiah

dalam Bidang Teknik Industri

\begin{tabular}{|l|ll|}
\hline & 98 \\
\hline Kegiatan H & Kegiatan E \\
$\mathrm{D}-\mathrm{H}$ & $\mathrm{LS}=98-49 \quad=49$ \\
$\mathrm{ES}=22+10=32$ & $\mathrm{LF}=49+49 \quad=$ \\
$\mathrm{EF}=32+21=53$ & 98 & \\
$\mathrm{E}-\mathrm{H}$ & & \\
$\mathrm{ES}=49+10=59$ & & \\
$\mathrm{EF}=59+21=80$ & & \\
$\mathrm{~F}-\mathrm{H}$ & & \\
$\mathrm{ES}=49+10=59$ & & \\
$\mathrm{EF}=59+21=80$ & & \\
$\mathrm{G}-\mathrm{H}$ & & \\
$\mathrm{ES}=49+10=59$ & $\mathrm{Kegiatan} \mathrm{D}$ & \\
$\mathrm{EF}=59+21=80$ & $\mathrm{LS}=77-28$ & $=49$ \\
\hline Kegiatan I & $\mathrm{LF}=49+28$ & $=$ \\
$\mathrm{ES}=59+6=65$ & 77 \\
$\mathrm{EF}=65+37=102$ & Kegiatan C \\
\hline Kegiatan J & \\
\hline
\end{tabular}

\begin{tabular}{|l|lr|}
\hline $\mathrm{ES}=59+6=65$ & $\mathrm{LS}=76-54$ & $=22$ \\
$\mathrm{EF}=65+63=128$ & $\mathrm{LF}=22+54$ & $=$ \\
& 76 & $=49$ \\
\hline Kegiatan K & Kegiatan $\mathrm{B}$ & \\
$\mathrm{I}-\mathrm{K}$ & $\mathrm{LF}=49-0$ & \\
$\mathrm{ES}=65+17=82$ & $\mathrm{LS}=49-26$ & \\
$\mathrm{EF}=82+21=103$ & & \\
$\mathrm{~J}-\mathrm{K}$ & & \\
$\mathrm{ES}=65+17=82$ & & \\
$\mathrm{EF}=82+21=103$ & Kegiatan A & \\
\hline $\mathrm{Kegiatan} \mathrm{L}$ & $\mathrm{B}-\mathrm{A}$ & \\
$\mathrm{ES}=82+20=102$ & $\mathrm{LF}=23-0$ & $=1$ \\
$\mathrm{EF}=102+8=110$ & 23 & $=$ \\
& $\mathrm{LS}=23-22$ & $=1$ \\
& $\mathrm{C}-\mathrm{A}$ & \\
& $\mathrm{LF}=22-0$ & $=$ \\
& 22 & \\
& $\mathrm{LS}=22-22$ & $=0$ \\
\end{tabular}

(Sumber : Pengolahan Data, 2015)

Berdasarkan hasil perhitungan di atas, maka diperoleh hasil sebagai berikut:

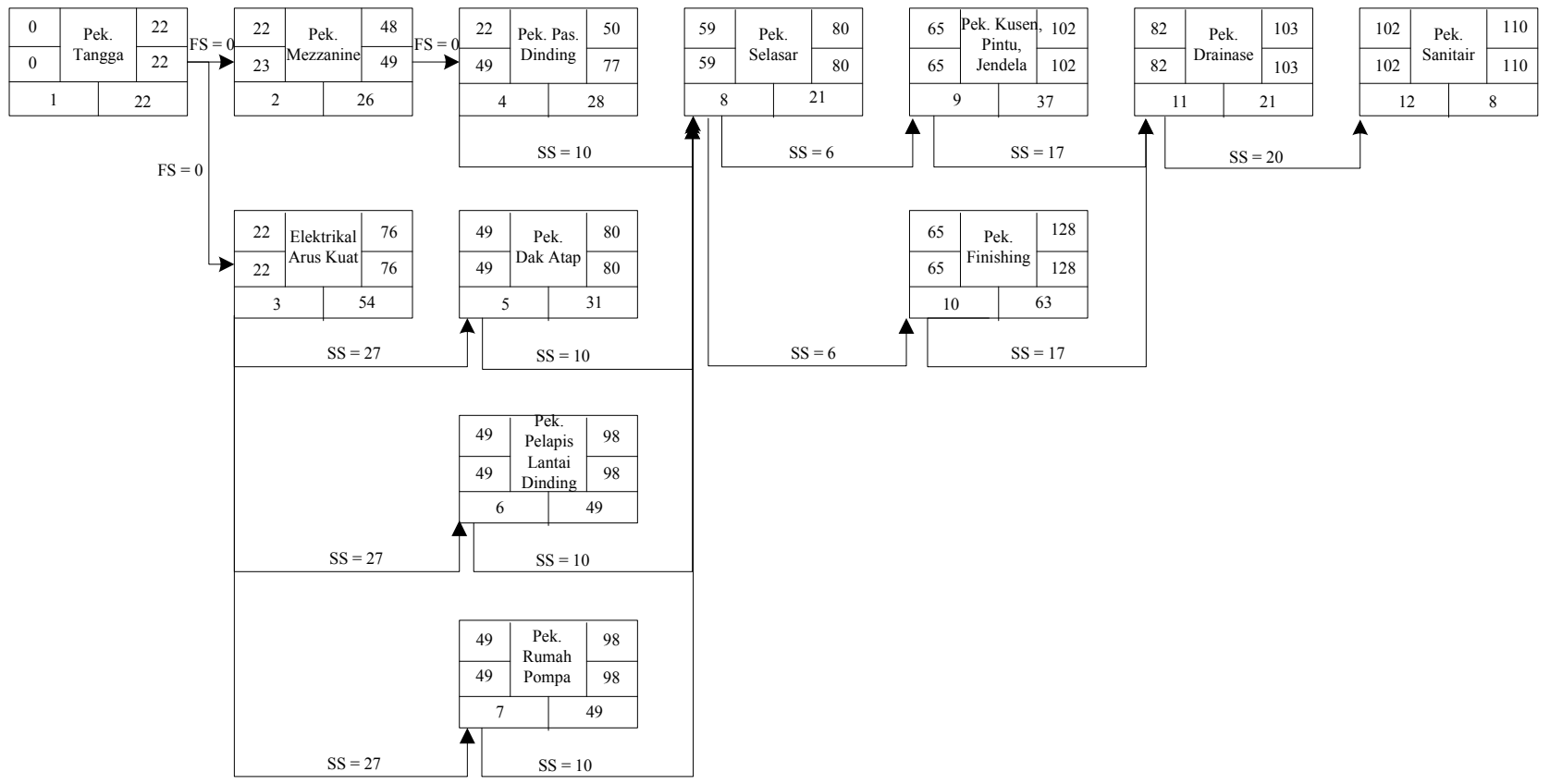

Gambar 4. Precedence Diagram Proyek Main Power House (MPH) Berdasarkan Perhitungan Maju dan Perhitungan Mundur

(Sumber: Pengolahan Data, 2015)

\section{Perhitungan Lintasan Kritis}

Perhitungan lintasan kritis dilakukan untuk mengetahui kegiatan-kegiatan yang bersifat kritis atau tidak dapat ditunda pekerjaannya. Adapun perhitungannya adalah sebagai berikut:

Total float $=0=\mathrm{LF}-\mathrm{EF}=\mathrm{LS}-\mathrm{ES}$

Berikut adalah hasil dari perhitungan lintasan kritis:

Tabel 7. Perhitungan Lintasan Kritis

\begin{tabular}{|l|l|l|}
\hline Kegiatan & Perhitungan Total Float & Keterangan \\
\hline
\end{tabular}

\begin{tabular}{|c|c|c|c|}
\hline A & $\begin{array}{ll} & \mathrm{LF}-\mathrm{EF}=22 \\
0 & \mathrm{LS}-\mathrm{ES}=0 \\
0 & \end{array}$ & $\begin{array}{l}-22= \\
-0=\end{array}$ & $\begin{array}{c}\text { Lintasan } \\
\text { kritis }\end{array}$ \\
\hline B & $\begin{array}{ll} & \mathrm{LF}-\mathrm{EF}=49 \\
1 & \mathrm{LS}-\mathrm{ES}=23 \\
1 & \end{array}$ & $\begin{array}{l}-48= \\
-22=\end{array}$ & $\begin{array}{c}\text { Tidak } \\
\text { lintasan } \\
\text { kritis }\end{array}$ \\
\hline $\mathrm{C}$ & $\begin{array}{ll} & \mathrm{LF}-\mathrm{EF}=76 \\
0 & \\
& \mathrm{LS}-\mathrm{ES}=22 \\
0 & \end{array}$ & $\begin{array}{l}-76= \\
-22=\end{array}$ & $\begin{array}{c}\text { Lintasan } \\
\text { kritis }\end{array}$ \\
\hline
\end{tabular}




\begin{tabular}{|c|c|c|c|}
\hline Kegiatan & Perhitungan Tota & Float & Keterangan \\
\hline D & $\begin{array}{l}{ }_{27} \mathrm{LF}-\mathrm{EF}=77 \\
27\end{array}$ & $\begin{array}{l}-50= \\
-22=\end{array}$ & $\begin{array}{c}\text { Tidak } \\
\text { lintasan } \\
\text { kritis }\end{array}$ \\
\hline E & $\begin{array}{ll} & \mathrm{LF}-\mathrm{EF}=80 \\
0 & \\
& \mathrm{LS}-\mathrm{ES}=49 \\
0 & \end{array}$ & $\begin{array}{l}-80= \\
-49=\end{array}$ & $\begin{array}{c}\text { Lintasan } \\
\text { kritis }\end{array}$ \\
\hline$F$ & $\begin{array}{ll} & \mathrm{LF}-\mathrm{EF}=98 \\
0 & \\
& \mathrm{LS}-\mathrm{ES}=49 \\
0 & \end{array}$ & $\begin{array}{l}-98= \\
-49=\end{array}$ & $\begin{array}{c}\text { Lintasan } \\
\text { kritis }\end{array}$ \\
\hline $\mathrm{G}$ & $\begin{array}{ll} & \mathrm{LF}-\mathrm{EF}=98 \\
0 & \\
& \mathrm{LS}-\mathrm{ES}=49 \\
0 & \end{array}$ & $\begin{array}{l}-98= \\
-49=\end{array}$ & $\begin{array}{c}\text { Lintasan } \\
\text { kritis }\end{array}$ \\
\hline $\mathrm{H}$ & $\begin{array}{ll} & \mathrm{LF}-\mathrm{EF}=80 \\
0 & \\
& \mathrm{LS}-\mathrm{ES}=59 \\
0 & \\
\end{array}$ & $\begin{array}{l}-80= \\
-59=\end{array}$ & $\begin{array}{c}\text { Lintasan } \\
\text { kritis }\end{array}$ \\
\hline I & $\begin{array}{ll} & \mathrm{LF}-\mathrm{EF}=102 \\
0 & \mathrm{LS}-\mathrm{ES}=65 \\
0 & \end{array}$ & $\begin{array}{l}-102= \\
-65=\end{array}$ & $\begin{array}{c}\text { Lintasan } \\
\text { kritis }\end{array}$ \\
\hline
\end{tabular}

\begin{tabular}{|c|c|c|c|}
\hline $\mathrm{J}$ & 0 & $\begin{array}{l}\mathrm{LF}-\mathrm{EF}=128-128= \\
\mathrm{LS}-\mathrm{ES}=65-65=\end{array}$ & $\begin{array}{c}\text { Lintasan } \\
\text { kritis }\end{array}$ \\
\hline $\mathrm{K}$ & 0 & $\begin{array}{l}\mathrm{LF}-\mathrm{EF}=103-103= \\
\mathrm{LS}-\mathrm{ES}=82-82=\end{array}$ & $\begin{array}{c}\text { Lintasan } \\
\text { kritis }\end{array}$ \\
\hline $\mathrm{L}$ & 0 & $\begin{array}{l}\mathrm{LF}-\mathrm{EF}=110-110= \\
\mathrm{LS}-\mathrm{ES}=102-102=\end{array}$ & $\begin{array}{c}\text { Lintasan } \\
\text { kritis }\end{array}$ \\
\hline
\end{tabular}

(Sumber : Pengolahan Data, 2015)

Berdasarkan perhitungan lintasan krits di atas, berikut adalah diagram network-nya:

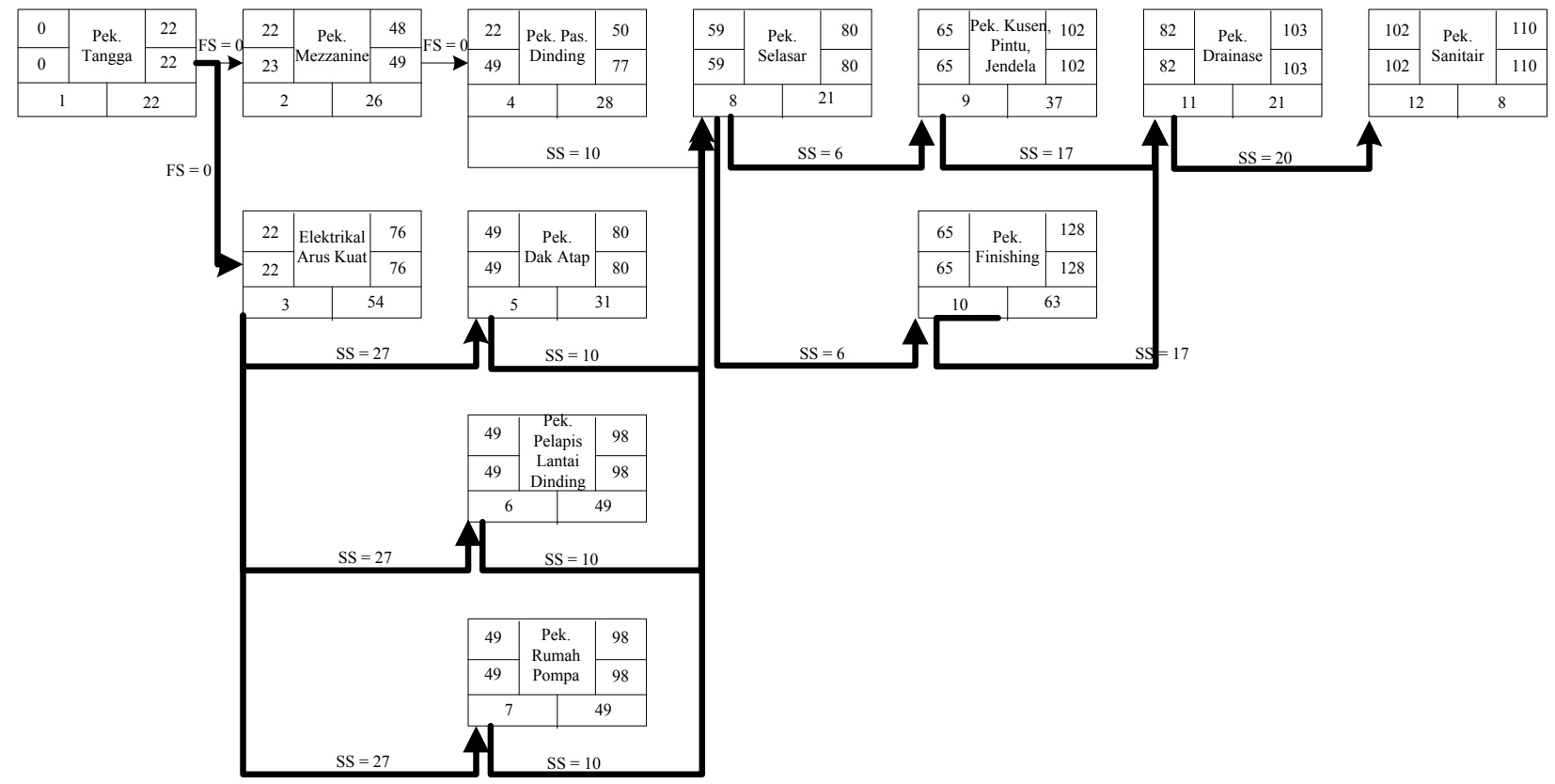

Gambar 5. Precedence Diagram Proyek Main Power House (MPH) Berdasarkan Lintasan Kritis

(Sumber : Pengolahan Data, 2015)

Berdasarkan perhitungan diagram network PDM yang telah dibuat, maka diperoleh waktu penyelesaian proyek yaitu 110 hari, dengan kegiatan yang tidak bisa ditunda pengerjaannya yaitu kegiatan A-C-E-F-G-H-I-J-K-L atau kegiatan pekerjaan tangga, pekerjaan elektrikal arus kuat, pekerjaan dak atap, 
pekerjaan pelapis lantai dinding, pekerjaan rumah pompa, pekerjaan selasar, pekerjaan kusen, pintu, jendela, pekerjaan drainase dan pekerjaan sanitair.

\section{Probabilitas PERT (Project Evaluation and Review Technique)}

Pada penelitian ini, perhitungan probailitas menggunakan metode PERT dilakukan dengan pendekatan metode PDM sehingga diagram network pada metode ini sama dengan metode PDM.

Tabel 8. Estimasi Durasi PERT

\begin{tabular}{|l|c|c|c|}
\hline \multirow{2}{*}{\multicolumn{1}{|c|}{ Kegiatan }} & \multicolumn{3}{c|}{ Durasi (Hari) } \\
\cline { 2 - 4 } & a & m & b \\
\hline Pekerjaan Tangga & 19 & 22 & 25 \\
\hline $\begin{array}{l}\text { Pekerjaan Mezzanine Diruang } \\
\text { Gudang Oli }\end{array}$ & 23 & 26 & 29 \\
\hline Elektrikal Arus Kuat & 51 & 54 & 57 \\
\hline Pekerjaan Pasangan Dinding & 24 & 28 & 32 \\
\hline Pekerjaan Dak Atap & 27 & 31 & 33 \\
\hline $\begin{array}{l}\text { Pekerjaan Pelapis Lantai \& } \\
\text { Dinding }\end{array}$ & 47 & 49 & 52 \\
\hline Pekerjaan Rumah Pompa & 46 & 49 & 51 \\
\hline Pekerjaan Selasar & 19 & 21 & 23 \\
\hline Pekerjaan Kusen, Pintu, Jendela & 33 & 37 & 41 \\
\hline Pekerjaan Finishing & 61 & 63 & 65 \\
\hline Pekerjaan Drainase Terbuka & 18 & 21 & 25 \\
\hline Pekerjaan Sanitair & 6 & 8 & 11 \\
\hline
\end{tabular}

(Sumber : Pengolahan Data, 2015)

Setelah dilakukan estimasi durasi untuk perhitungan probabilitas PERT, maka selanjutnya adalah perhitungan mean durasi kegiatan yang diharapkan serta standar deviasi. Berikut adalah rumus yang digunakan:

$$
\begin{aligned}
& \mathrm{te}=\frac{\mathrm{a}+4 \mathrm{~m}+\mathrm{b}}{6} \\
& \mathrm{~s}=\frac{\mathrm{b}-\mathrm{a}}{6}
\end{aligned}
$$

1. Pekerjaan tangga

$$
\begin{aligned}
& \text { te }=\frac{19+4(22)+25}{6} \\
& =22 \\
& \mathrm{~s}=\frac{25-19}{6} \\
& =1
\end{aligned}
$$

Berikut adalah rekapitulasi estimasi durasi
Tabe19. Rekapitulasi Estimasi Durasi PERT

\begin{tabular}{|l|c|c|c|c|c|c|}
\hline \multirow{2}{*}{ Kegiatan } & \multicolumn{7}{|c|}{$\begin{array}{c}\text { Durasi } \\
\text { (Hari }\end{array}$} & \multicolumn{2}{c|}{} \\
\cline { 2 - 7 } & a & m & b & te & s & $\mathbf{s}^{2}$ \\
\hline $\begin{array}{l}\text { Pekerjaan } \\
\text { Tangga }\end{array}$ & 19 & 22 & 25 & 22,00 & 1,00 & 1,00 \\
\hline $\begin{array}{l}\text { Pekerjaan } \\
\text { Mezzanine } \\
\begin{array}{l}\text { Diruang Gudang } \\
\text { Oli }\end{array}\end{array}$ & 20 & 26 & 29 & 25,50 & 1,50 & 2,25 \\
\hline $\begin{array}{l}\text { Elektrikal Arus } \\
\text { Kuat }\end{array}$ & 51 & 54 & 59 & 54,33 & 1,33 & 1,78 \\
\hline $\begin{array}{l}\text { Pekerjaan } \\
\text { Pasangan } \\
\text { Dinding }\end{array}$ & 24 & 28 & 32 & 28,00 & 1,33 & 1,78 \\
\hline $\begin{array}{l}\text { Pekerjaan Dak } \\
\text { Atap }\end{array}$ & 27 & 31 & 33 & 30,67 & 1,00 & 1,00 \\
\hline $\begin{array}{l}\text { Pekerjaan Pelapis } \\
\text { Lantai \& } \\
\text { Dinding }\end{array}$ & 45 & 49 & 52 & 48,83 & 1,17 & 1,36 \\
\hline $\begin{array}{l}\text { Pekerjaan Rumah } \\
\text { Pompa }\end{array}$ & 46 & 49 & 51 & 48,83 & 0,83 & 0,69 \\
\hline
\end{tabular}

(Sumber : Pengolahan Data, 2015)

Tabel 10. Rekapitulasi Estimasi Durasi PERT (Lanjutan)

\begin{tabular}{|l|c|c|c|c|c|c|}
\hline \multirow{2}{*}{ Kegiatan } & \multicolumn{3}{|c|}{$\begin{array}{c}\text { Durasi } \\
\text { (Hari) }\end{array}$} & \multicolumn{2}{|c|}{} \\
\cline { 2 - 7 } & a & m & b & te & s & $\mathbf{s}^{2}$ \\
\hline Pekerjaan Selasar & 19 & 21 & 25 & 21,33 & 1,00 & 1,00 \\
\hline $\begin{array}{l}\text { Pekerjaan Kusen, } \\
\text { Pintu, Jendela }\end{array}$ & 33 & 37 & 41 & 37,00 & 1,33 & 1,78 \\
\hline $\begin{array}{l}\text { Pekerjaan } \\
\text { Finishing }\end{array}$ & 58 & 63 & 65 & 62,50 & 1,17 & 1,36 \\
\hline $\begin{array}{l}\text { Pekerjaan } \\
\text { Drainase } \\
\text { Terbuka }\end{array}$ & 18 & 21 & 27 & 21,50 & 1,50 & 2,25 \\
\hline $\begin{array}{l}\text { Pekerjaan } \\
\text { Sanitair }\end{array}$ & 6 & 8 & 11 & 8,17 & 0,83 & 0,69 \\
\hline
\end{tabular}

(Sumber : Pengolahan Data, 2015) 
Berdasarkan nilai te (durasi yang diharapkan) pada perhitungan di atas, maka dibuat diagram network dengan pendekatan PDM. Adapun diagram network PERT adalah sebagai berikut:

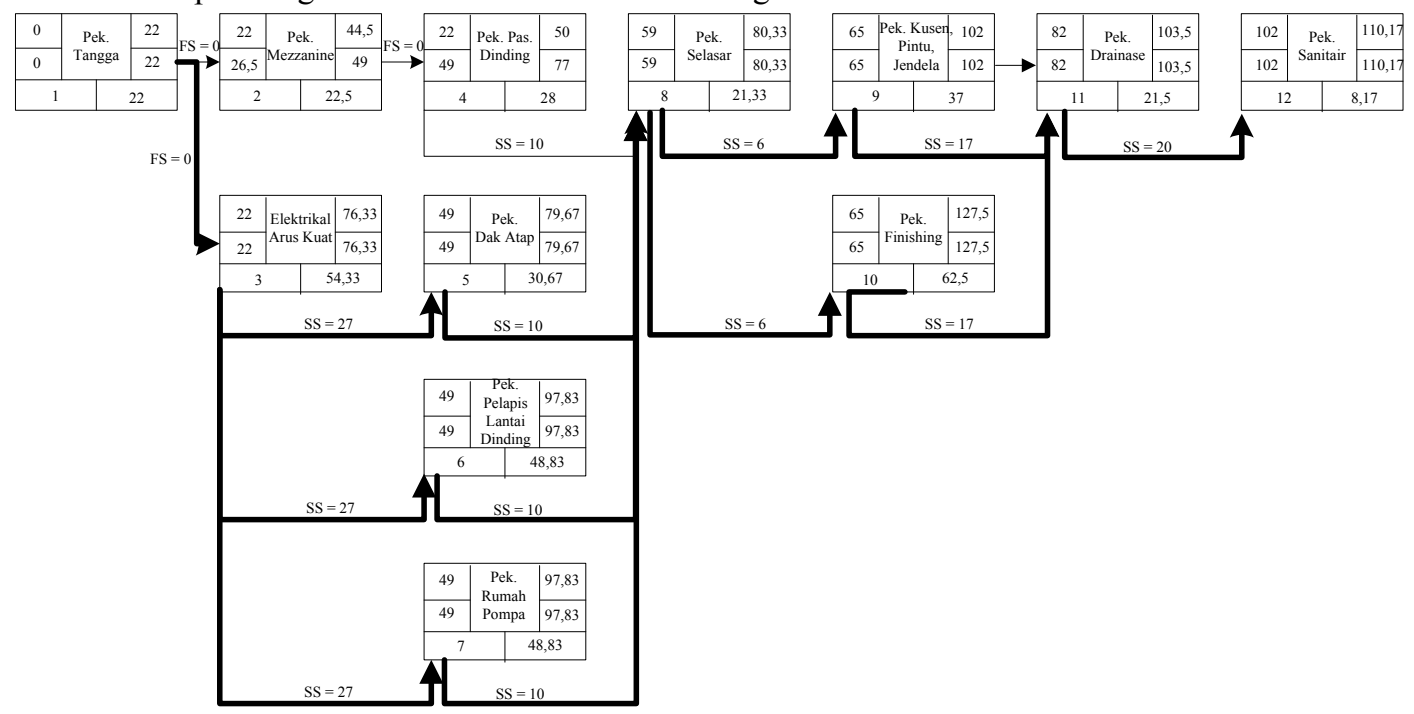

Gambar 6.Diagram Network Proyek Main Power House (MPH) Metode PERT

(Sumber: Pengolahan Data, 2015)

Adapun perhitungan kemungkinan/ probabilitas waktu penyelesaian proyek Main Power House (MPH) dengan durasi waktu yang dijadwalkan Ts $=110$ hari (diambil dari durasi penyelesaian proyek dengan PDM) adalah sebagai berikut:

Te adalah jumlah dari te untuk kegiatan kritis atau sama dengan total waktu penyelesaian proyek yang diharapkan, lintasan kritis proyek Main Power House (MPH) dengan metode PERT adalah kegiatan A-C-E-F-G-H-I-J-K-L atau kegiatan pekerjaan tangga, pekerjaan elektrikal arus kuat, pekerjaan dak atap, pekerjaan pelapis lantai dinding, pekerjaan rumah pompa, pekerjaan selasar, pekerjaan kusen, pintu, jendela, pekerjaan drainase dan pekerjaan sanitair dengan total durasi proyek tercepat yan diharapkan Te $=110,17$ hari. Sedangkan standar deviasi dan distribusi durasi proyek yang diharapkan adalah sebagai berikut: Ts $=110$ hari

$\mathrm{Te}=110,17$ hari

$\mathrm{S}=\sqrt{\sum s^{2}}$ untuk kegiatan kritis

$S=\sqrt{\begin{array}{c}(1,00+2,25+1,78+1,78+1,00+1,36 \\ +0,69+1,00+1,78+1,36+2,25+0,69)\end{array}}$
$\mathrm{S}=\sqrt{16,94}$

$\mathrm{S}=4,12$

$\mathrm{Z}=\frac{\mathrm{Ts}-\mathrm{Te}}{\mathrm{S}}$

$\mathrm{Z}=\frac{110-110,17}{4,12}$

$\mathrm{Z}=-0,04 \rightarrow$ Lihat nilai distribusi tabel $\mathrm{Z}$

$=0,48$

$=1-0,48$

$=0,52 \approx 52 \%$

Berdasarkan perhitungan di atas, maka dapat diketahi bahwa kemungkinan waktu penyelesaian proyek Main Power House (MPH) dengan waktu toal penyelesaian proyek 110 hari adalah $52 \%$.

\section{Perhitungan Crash Project}

Perhitungan crash project atau percepatan proyek dilakukan dengan kerja lembur yang dilakukan 
oleh pekerja, sehingga erat hubungannya dengan upah yang diterima oleh setiap pekerja. Pada crash project ini, kegiatan yang dilakukan percepatan durasi adalah kegiatan yang memiliki durasi paling lama yang ada pada lintasan kritis, yaitu kegiatan finishingdengan durasi 63 hari. Perihitungan durasi proyek menggunakan pendekatan PDM, yaitu dengan total waktu proyek 110 hari dengan nilai Rp 70,903,850.00.

Adapun crash project kegiatan finishing dapat dilihat sebagai berikut:

Diketahui:

Bobot kegiatan finishing $=\operatorname{Rp} 70,903,850.00$

Bobot keseluruhan proyek $=\mathrm{Rp} 1,141,993,911.10$

Waktu kegiatan finishing $=63$ hari

Waktu kegiatan proyek $=110$ hari

1. Pengurangan durasi pekerjaan 1 hari (62 hari)

a. Perhitungan Bobot Pekerjaan $=\frac{70,903,850.00}{1,141,993,911.10} \times 100 \%=6,21 \% \approx 0,06$

b. Waktu Normal Perkerjaan $=110$ Hari

c. Waktu Perkerjaan Dipercepat $=1$ Hari

d. Waktu Setelah Dipercepat $=110-1$ $=109$ Hari

e. Volume Pekerjaan Normal/Hari $=\frac{0,06}{110}=0,00099$

Berikut adalah rekapitulasi crash project hingga mendapatkan biaya optimal.

Tabel 11. Rekapitulasi Perhitungan Crash Project

\begin{tabular}{|c|c|c|c|c|}
\hline $\begin{array}{c}\text { Crash } \\
\begin{array}{c}\text { Duration } \\
\text { (Hari) }\end{array}\end{array}$ & $\begin{array}{c}\text { Durasi } \\
\text { (Hari) }\end{array}$ & Biaya Langsung (Rp) & $\begin{array}{c}\text { Biaya Tidak } \\
\text { Langsung (Rp) }\end{array}$ & Total Biaya (Rp) \\
\hline 0 & 63 & $1.141 .993 .911,10$ & $26.776 .580,32$ & $1.168 .770 .491,42$ \\
\hline 1 & 62 & $1.142 .016 .265,94$ & $26.533 .107,81$ & $1.168 .549 .373,75$ \\
\hline 2 & 61 & $1.142 .084 .796,35$ & $26.289 .684,81$ & $1.168 .374 .481,15$ \\
\hline 3 & 60 & $1.142 .201 .811,10$ & $26.046 .261,80$ & $1.168 .248 .072,90$ \\
\hline 4 & 59 & $1.142 .369 .775,51$ & $25.802 .838,79$ & $1.168 .172 .614,30$ \\
\hline 5 & 58 & $1.142 .591 .324,89$ & $25.559 .415,78$ & $1.168 .150 .740,68$ \\
\hline 6 & 57 & $1.142 .869 .279,52$ & $25.315 .992,78$ & $1.168 .185 .272,30$ \\
\hline 7 & 56 & $1.143 .206 .661,10$ & $25.072 .569,77$ & $1.168 .279 .230,87$ \\
\hline 8 & 55 & $1.143 .606 .711,10$ & $24.829 .146,76$ & $1.168 .435 .857,86$ \\
\hline 9 & 54 & $1.168 .658 .634,00$ & $24.585 .723,75$ & $1.168 .658 .634,85$ \\
\hline 10 & 53 & $1.144 .609 .005,00$ & $24.342 .300,75$ & $1.168 .951 .306,19$ \\
\hline
\end{tabular}

(Sumber: Pengolahan Data, 2015)

Berdasarkan tabel di atas, maka dapat dilihat dengan percepatan durasi sebanyak 5 hari akan menambah biaya optimal yaitu Rp 1.168.150.740,68

Berikut adalah grafik perbandingan percepatan durasi proyek: f. Volume Pekerjaan Dipercepat/Hari $=\frac{0,06}{109}=0,00100$

g. Tambahan Waktu Lembur $=\frac{0,00100-0,00099}{0,000099} \times 8=0,11 \mathrm{Jam}$

Karena tambahan waktu lembur diperoleh kurang dari 6 jam, maka upah yang dikenakan adalah jam lembur dikali upah standar per jam, sehingga:

h. Upah Lembur/Hari

0,11 x Rp 198.000= Rp 22.354,84

i. Biaya Langsung:

Rp 1.141.993.911,10+

(1 x Rp 22.354,84)

$=\operatorname{Rp} 1.142 .016 .265,94$

j. Biaya Tidak Langsung:

(Rp 26.776.530,82: 110) x 109

$=\operatorname{Rp} 26.533 .107,81$

k. Total Biaya

$=\mathrm{Rp} 1.142 .016 .265,94+\mathrm{Rp} 26.533 .107,81$

$=\mathrm{Rp} 1.168 .549 .373,75$ 


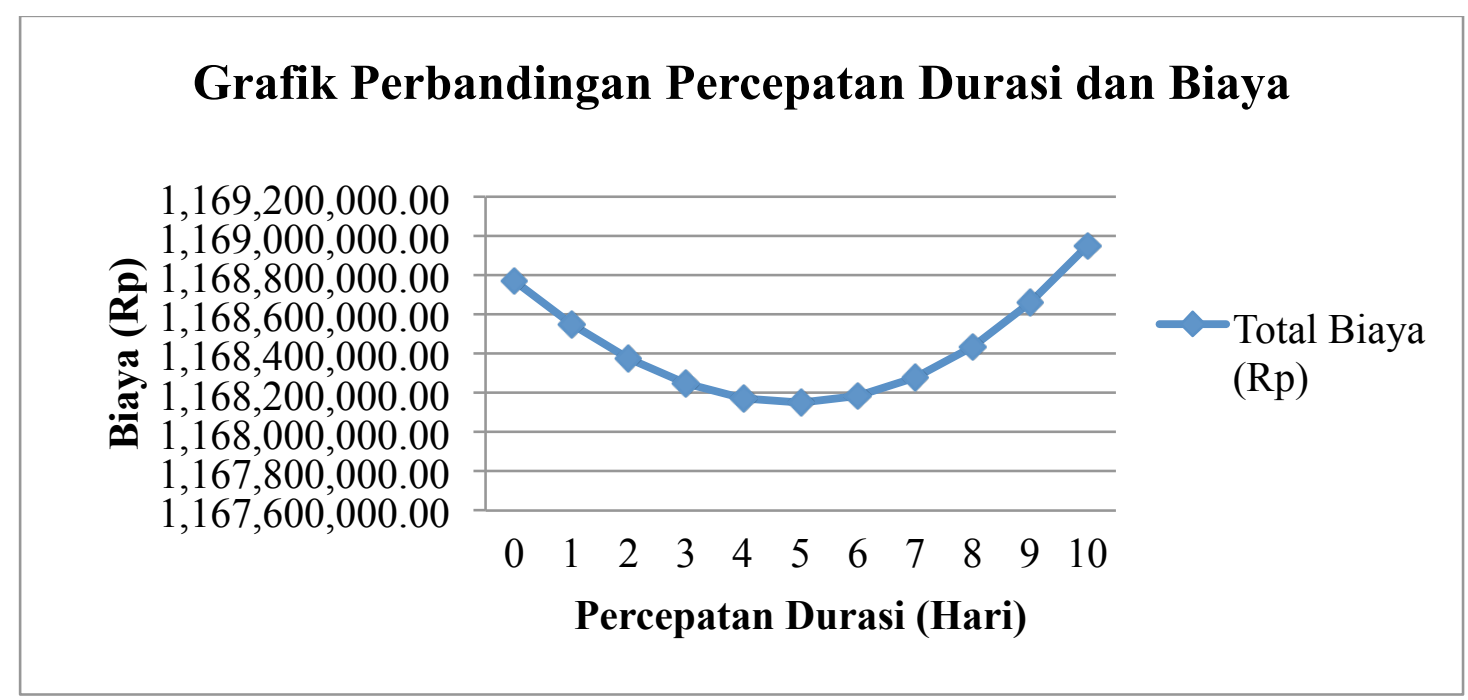

Gambar 4.8 Grafik Perbandingan Percepatan Durasi dan Biaya

(Sumber: Pengolahan Data, 2015)

Berdasarkan grafik di atas, dapat dilihat bahwa biaya optimum percepatan durasi adalah dengan mempercepat 5 hari kegiatan finishing yaitu dengan total biaya Rp 1.168.150.740,68. Jika percepatan durasi sebanyak 6 hari, maka total biaya akan lebih besar yaitu Rp 1.168.185.272,30.

\section{Kesimpulan}

Adapun kesimpulan pada penelitian ini adalah:

1. Jalur kritis pada proyek Gedung Main Power House (MPH) adalah kegiatan A-C-E-F-G-H-I-JK-L atau kegiatan pekerjaan tangga, pekerjaan elektrikal arus kuat, pekerjaan dak atap, pekerjaan pelapis lantai dinding, pekerjaan rumah pompa, pekerjaan selasar, pekerjaan kusen, pintu, jendela, pekerjaan drainase dan pekerjaan sanitair.

2. Probabilitas penyelesaian proyek selama 110 hari (dengan pendekatan PDM) adalah 52\%.

3. Biaya optimal proyek adalah sebesar Rp 1.168.150.740,68 dengan percepatan durasi kegiatan finishing sebanyak 5 hari.

\section{Daftar Pustaka}

Abisetyo. W. 2010. Penerapan Penjadwalan Probabilistik pada Proyek Pengembangan Gedung Fsaintek Unair. Jurnal.

Amani. W., Helmi., Beni. I. 2012. Perbandingan Aplikasi CPM, PDM, dan Teknik Bar ChartKurva S pada Optimalisasi Penjadwalan Proyek. Jurnal.
Arianto, A. 2010. Eksplorasi Metode Bar Chart, CPM, PDM, PERT, Line of Balance dan Time of Chainage Diagram dalam Penjadwalan Proyek Konstruksi. Tesis.

Arta. I. M. J. A. 2010. Analisa Optimasi Biaya dan Waktu Pada Proyek Lanjutan Tahap III Pembangunan Gedung Fakultas Teknologi Informasi (FTIF) ITS. Jurnal.

Christian., Cefiro., Sentosa. 2013. Studi Kasus Penerapan Metode Pert Pada Proyek Gudang X. Jurnal.

Dannyanti, E. 2011. Optimalisasi Pelaksanaan Proyek dengan Metode PERT dan CPM. Jurnal.

Frederika. A. 2010. Analisis Percepatan Pelaksanaan dengan Menambah Jam Kerja Optimum pada Proyek Konstruksi (Studi Kasus: Proyek Pembangunan Super Villa, Peti TengetBadung). Jurnal.

Gumilang. 2014. Metode PERT-CPM untuk Optimalisasi Penjadwalan Proyek (Studi Kasus Pembangunan Rusunawa Karangroto Semarang). Jurnal.

Gray. C. F dan Erik. W. L. 2007. Manajemen Proyek. Yogyakarta. Andi.

Lumbabatu. J. K., Syahrialz. 2013. Analisis Percepatan Waktu Proyek dengan Tambahan Biaya Yang Optimum (Studi Kasus : Proyek Pembangunan Gedung Sekolah Yayasan Pelita Bangsa di Jl. Iskandar Muda Medan, Sumatera Utara). Jurnal. 
Malingkas. G.Y ., Tisano. T. J. A, Huibert. T. 2013. Menganalisis Sensitivitas Keterlambatan Durasi Proyek Dengan Metode CPM (Studi Kasus: Perumahan Puri Kelapa Gading). Jurnal.

Raharja. I. 2014. Analisa Penjadwalan Proyek Dengan Metode PERT di PT. Hasana Damai Putra Yogyakarta pada Proyek Perumahan Tirta Sani. Jurnal.

Sahid. D.S.S. 2012. Implementasi Critical Path Method dan PERT Analysis pada Proyek Global Technology for Local Community. Jurnal.
Sasmoko. D. 2013. Penerapan Teknologi XML Web Service Perusahaan Manufaktur untuk Mengukur Waktu Kerja Menggunakan Metode CPM. Jurnal.

Somantri. A. 2005. Studi Tentang Perencanaan Waktu dan Biaya Proyek Penambahan Ruang Kelas di Politeknik Manufaktur pada PT Haryang Kuning. Jurnal. 